\title{
The Influence of Parenting Patterns on Stunting Incidences in Toddlers (Study in the Work Area of Sumberjambe Health Center, Kasiyan Health Center and Sumberbaru Health Center Jember Regency)
}

\author{
Ayik Nikmatul Laili ${ }^{1}$, Al \\ Munawir ${ }^{2}$, Farida Wahyu \\ Ningtyias $^{3}$ \\ ${ }^{1}$ D3 Midwifery, Faculty of \\ Health Sciences, Universitas \\ Bakti Indonesia \\ ${ }^{2}$ Department of Pathology, \\ Faculty of Medicine, University \\ of Jember Indonesia \\ ${ }^{3}$ Faculty of Public Health, \\ University of Jember Indonesia \\ Email: \\ aik.nikmah89@gmail.com
}

Received : October $4^{\text {nd }} 2021$

Accepted : October $15^{\text {rd }} 2021$

Published : November $27^{\text {th }} 2021$

\begin{abstract}
Stunting is a form of long-term reflection of the quality and quantity of food consumed is inadequate and often suffers from infectious diseases in childhood. The problem of stunting is a nutritional problem that needs attention because it can affect the quality of human resources. Stunting problems, especially those that occur in toddlers, are considered serious because stunting conditions in toddlers can cause delays in motor development and decrease intelligence levels. The type of research used in this study is an analytical observational study with a case control research design. The results of data analysis showed that there was an effect of parenting on the incidence of stunting in toddlers. The amount of risk is 5,1 which means that families who apply good parenting to toddlers will reduce the risk of stunting. This study is in line with research conducted by Rahmayana, et al (2014) which states that there is a significant relationship between parenting patterns and the incidence of stunting. Parenting patterns of parents to children in this case is the practice of giving food is an important foundation in growth. The role of parents, especially mothers when breastfeeding their children, when giving food, how to give food to children and controlling the portion size and nutritional content in children's food will improve nutritional status so that it will reduce the incidence of stunting in children. The solution to this problem is to screen children under five to detect stunting.
\end{abstract}

Keywords: Parenting, stunting

Copyright $@ 2021$ IIK STRADA Indonesia All right reserved.

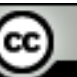

This is an open-acces article distributed under the terms of the Creative Commons Attribution-ShareAlike 4.0 International License.

\section{INTRODUCTION}

Stunting is a form of long-term reflection of the quality and quantity of food consumed is inadequate and often suffers from infectious diseases in childhood. The problem of stunting is a nutritional problem that needs attention because it can affect the quality of human resources. The Millennium Challenge Account Indonesia (2015) stated that the prevalence of stunting in Indonesia is higher than other countries in Southeast Asia, such as Myanmar (35\%), Vietnam (23\%), and Thailand (16\%). In Indonesia, an estimated 7.8 million children under 5 years of age are stunted, this data is based on a report released by UNICEF. The prevalence of stunting children under five in Indonesia based on the results of the 2013 Riskesdas reached $37.2 \%$ and was ranked 24th out of 32 
provinces in Indonesia. The incidence of stunting at Riskesdas in 2010 was $35.6 \%$ and in 2007 was $36.8 \%$. Short prevalence was $37.2 \%$ consisting of $18.0 \%$ very short and $19.2 \%$ short. In 2013 the prevalence of very short showed a decrease from $18.8 \%$ in 2007 and $18.5 \%$ in 2010, while the prevalence of shortness increased from $18.0 \%$ in 2007 to $19.2 \%$ in 2013.

Stunting problems, especially those that occur in toddlers, are considered serious because stunting conditions in toddlers can cause delays in motor development and decrease intelligence levels. Another impact that arises is that it can cause depression of immune function, metabolic changes, decreased motor development, decreased cognitive values and academic values. Children who experience stunting will have long-term impacts, including the risk of obesity, glucose tolerance, coronary heart disease, hypertension, osteoporosis, decreased performance and productivity (Eltaguri et al, 2008).

The problem of stunting is determined by the factors that influence it. These factors in each region can be different from each other. UNICEF (1998) suggests that growth is influenced by direct and indirect causes. Direct causes include food intake and health conditions, while indirect causes include household food security, child care patterns, environmental sanitation and utilization of health services. These factors are determined by human, economic and organizational resources through educational factors. The most basic cause of growth and development comes from problems of political, ideological, and socio-economic structures which are based on the potential of existing resources (Supariasa et al., 2012).

One of the causes of stunting is parenting in giving food to toddlers. Another study conducted by Roenyoet, et.al (2013) also stated that there was a relationship between parenting patterns and the incidence of stunting in children. Feeding babies is categorized into 2 parts, namely breastfeeding (Mother's Milk) for infants aged 0-6 months and providing complementary foods (MP-ASI) for infants starting at 6 months of age. Breastfeeding for babies starting at the age of 0-6 months is called exclusive breastfeeding, which is only giving breast milk for 6 months without giving other food or drinks. Giving additional fluids will increase the risk of disease because the provision of additional fluids and food can be a means of entry of pathogenic bacteria (Yuliarti, 2010). After the age of 6 months, babies begin to need solid foods with several nutrients, such as iron, vitamin C, protein, zinc, water, and calories. Therefore, it is also important not to delay until the baby is more than 6 months old because delaying can cause growth disorders (Prabantini, 2010). There are several factors that determine the amount of energy needed, such as age, ambient temperature, the baby's own activity, and gender. Therefore, the purpose of complementary feeding is primarily to increase energy and essential nutrients, so solid food for each feeding must contain more energy and nutrients than the formula it replaces.

The results of the Nutrition Status Determination (PSG) survey of the East Java Provincial Health Office, in 2013 the percentage of stunting in Jember Regency was 43.3\%. Based on the results of a preliminary study conducted at the Jember District Health Office, data was obtained that from a total of 50 Puskesmas in Jember Regency, there were 32 health centers of which stunting occurred. The results of interviews with the information staff of the District Health Office. Jember (2017), obtained data on the prevalence of stunting under five in 2016 the highest was in the work area of the Sumberjambe Health Center as much as $35 \%$, the second highest was in the working area of the Kasiyan Health Center as much as $32 \%$, and the third highest was in the work area of the Sumberbaru Health Center as much as $28 \%$.

Researchers feel the need to conduct research on the analysis of the determinants of stunting in toddlers. The reason for doing it on toddlers is because toddlerhood is the peak of cell growth and development where if the child's health problems are disturbed it will affect the growth and development process. This research will be conducted in three Puskesmas areas which are the areas with the highest stunting incidence in 2016, namely in the working area of Sumberjambe Health Center, Kasiyan Health Center and Sumberbaru Health Center. 


\section{MATERIALS AND METHODS}

The type of research used in this study is an analytical observational study with a case control research design. The study was conducted in the working area of the Jember District Health Center which had stunting under five in three Puskesmas with the highest number in 2016. The implementation time was carried out from September to October 2017. The independent variable in this study was parenting while the dependent variable was stunting. The case population in this study was 3890 stunted toddlers, while the control population was 8569 of the total children who were not stunted. The sampling technique in this study was cluster random sampling with a total sample of 71 cases and 71 controls. The data collection technique used the interview method with the research instrument using a questionnaire.

\section{RESULTS}

Table 1. Analysis of the Effect of Parenting on Stunting Incidence in Toddlers

Table 1. Analysis of the Effect of Parenting on Stunting Incidents in Toddlers

\begin{tabular}{cccccccccc}
\hline \multirow{2}{*}{$\begin{array}{c}\text { Parentin } \\
\mathrm{g}\end{array}$} & \multicolumn{4}{c}{ Stunting Incident } & \multicolumn{2}{c}{ Total } & \multirow{2}{*}{ Sig. } & \multirow{2}{*}{$B$} & \multirow{2}{*}{$\operatorname{Exp}(B)$} \\
\cline { 2 - 6 } & $\mathrm{n}$ & $\%$ & $\mathrm{n}$ & $\%$ & $\mathrm{~N}$ & $\%$ & & & 5.096 \\
\hline Bad & 53 & 67.1 & 26 & 32.9 & 79 & 100 & 0.000 & 1,628 & \\
Well & 18 & 28.6 & 45 & 71.4 & 63 & 100 & & & \\
\hline
\end{tabular}

The results of data analysis showed that there was an effect of parenting on the incidence of stunting in toddlers. The magnitude of the risk is 5.1, which means that families who apply good parenting to toddlers will reduce the risk of stunting. On the other hand, families who apply poor parenting will increase the risk of stunting in toddlers. The influence coefficient value of 1.7 indicates that there is a unidirectional effect between household food security on the incidence of stunting.

\section{DISCUSSION}

The results of this study indicate that there is an effect of parenting on the incidence of stunting in toddlers. This study is in line with research conducted by Rahmayana, et al (2014) which states that there is a significant relationship between parenting patterns and the incidence of stunting. Parenting patterns of parents to children in this case is the practice of giving food is an important foundation in growth. The role of parents, especially mothers when breastfeeding their children, when giving food, how to give food to children and controlling the portion size and nutritional content in children's food will improve nutritional status so that it will reduce the incidence of stunting in children. Another study conducted by Roenyoet, et.al (2013) also stated that there was a relationship between parenting patterns and the incidence of stunting in children.

The parenting pattern of parents in the research area is classified as poor. This is because many parents do not give breast milk (ASI) exclusively, even if there are those who provide breast milk, it is added with other types of food or drinks starting from babies less than 6 months old. Food for children 0-6 months is breast milk only. At the age of 6-9 months, the child is given breast milk plus crushed fruit 1-2 times or can also be given soft food once and soft food 2 times. Children aged 9-12 months are still given breast milk, plus 1-2 times of fruit and 3 times of soft food. Children older than 1 year are still given breast milk plus 1-2 times fruit, staple foods and side dishes 4 times or more (Krisnatuti, 2000 in Ayu, 2008).

Breast milk (ASI) according to Sekartini and Jeanne (2013) is a complex biological fluid that contains all the nutrients needed for physical growth and development of a child. Breast milk is adjusted to the needs, growth rate of the baby, and breastfeeding habits. Infant growth requires adequate nutrition, so that it can ensure optimal growth and development. The best nutrition for babies in the first 6 months of life is breast milk. WHO and UNICEF recommend exclusive breastfeeding from birth to 6 months of age and infants should be breastfed frequently without time limit. After the age of 6 months, the baby will receive complementary foods (MP-ASI) according to his age; While breastfeeding is still given until the child is 2 years old or older. 
Breastfed babies generally grow rapidly in the first 2-3 months of life, but more slowly than babies who are not exclusively breastfed. In the first week of life, weight loss of 5\% is common in formula-fed infants and 7\% in breast-fed infants. If there is a problem with breastfeeding, a weight loss of 7\% can occur in the first 72 hours of life, resulting in a decrease in the baby's immune system which causes various diseases to interfere with growth (Sekartini and Jeanne, 2013). Research conducted by Damayanti, et al (2016) argues that toddlers with a history of receiving non-exclusive breastfeeding have a 16.5 times greater risk of stunting than toddlers with a history of exclusive breastfeeding. Toddlers with a history of non-exclusive breastfeeding are more at risk for stunting because this is related to the incidence of infectious diseases such as diarrhea which is more common in infants under 6 months who are given food other than breast milk. The occurrence of infectious diseases causes a decrease in appetite, a decrease in nutrient absorption and an increase in catabolism so that nutrients are not sufficient for growth (Lestari et al., 2014).

Another reason is because parents do not provide various types of food. Parents prefer to give instant food and don't bother when processing it, such as giving instant porridge. The next cause is because children do not like certain types of food, and children do not want to eat if they are not given their favorite food. This is what makes parents only give food that only children like. Parents, especially mothers, do not try to persuade or modify food so that children are interested in eating. When daily nutritional needs are not met, children can experience many health risks and also in their development, such as obesity, heart attack, stroke, cancer, and other diseases. Bad eating habits in childhood will also usually have an impact on children's eating habits later in life. The growth period of children's food tastes usually begins to form so that, ifhard to eat childa certain food this can continue to carry over into adulthood. If children do not like a type of food that is actually beneficial for their health, parents should immediately deal with it from an early age, especially during growth, children need a variety of nutrients for their development (Sulistyoningsih, 2011).

\section{CONCLUSION}

Poor parenting will increase the risk of stunting in toddlers. The solution is that health workers need to socialize about screening for stunting, especially in toddlers to prevent stunting and increase public knowledge, especially parents who have children under five by providing education about needs starting during pregnancy until children enter toddlerhood. The hope is that people will better understand the nutritional content in food and can provide food according to the nutritional needs of children. In addition, the importance of educating the public about the use of simple food ingredients that are easy to find and cheap so that they do not require large amounts of expenditure and can be reached by all levels of society.

\section{ACKNOWLEDGMENTS}

The author is thankful for respondents for their valuable information and its awareness to participate in this research.

\section{CONFLICTS OF INTEREST:}

The author declares that they have no conflict of interest

\section{REFERENCES}

Damayanti, R. A., Lailatul, M., dan Farapti. (2016). Perbedaan Tingkat Kecukupan Zat Gizi dan Riwayat Pemberian ASI Eksklusif pada Balita Stunting dan Non Stunting. Jurnal Media Gizi Indonesia: 11(2): 61-69

Dinas Kesehatan Kabupaten Jember. (2015). Data Hasil PSG. Jember: Dinas Kesehatan Kabupaten Jember

El-Taguri, A., Ibrahim, B., Salah, M. M., dan Abdel, M. A. (2008). Risk Factors for Stunting Among Under-fives in Libya. Jurnal: Public Health Nutrition, 12(8):1141-1149.

Kementrian Kesehatan RI. (2010). Laporan Hasil Riset Kesehtan Dasar (Riskesdas) Tahun 2010. Jakarta: Kementrian Kesehatan RI

Riset Kesehatan Dasar (RISKESDAS). (2013). Badan Penelitian dan Pengembangan Kesehatan Kementerian Kesehatan RI Tahun 2013. Dilihat 29 November 2018 di pusdatin.kemkes.go.id 
Lestari, W., Margawati, A., dan Rahfiludin, M. (2014). Faktor Risiko Stunting pada Anak Umur 6-24 Bulan di Kecamatan Penanggalan Kota Subussalam Provinsi Aceh. Jurnal Gizi Indonesia, 3(1), 37-45.

Lutviana, E. dan Budiono, I. (2010). Prevalensi dan Determinan Kejadian Gizi Kurang pada Balita. ISSN: $1858-1196$

Maxwell, S. (2011). Module 5: Cause of Malnutrition. Dilihat 19 Mei 2017 di www.unsen.org

Oktarina, Z. dan Trini, S. (2013). Faktor Risiko Stunting pada Balita (24-59 bulan) di Sumatra. Jurnal Gizi dan Pangan: 8 (3): 175-180. ISSN 1978-1059.

Pahlevi, A. E. (2012). Determinan Status Gizi pada Siswa Sekolah Dasar. ISSN: 1196-1858

Prabatini, D. (2010). A to Z Makanan Pendamping ASI. Yogyakarta: ANDI

Prawirohartono, E.P., Astuti, H., dan Rennaningtyas, D. (2009). Menu Sehari-hari untuk Tumbuh Kembang Anak. Jakarta: Agro Media Pustaka

Proverawati, A. dan Asfufah, S. (2009). Buku Ajar Gizi untuk Kebidanan. Yogyakarta: Nuha Medika

Rahmayana, Irvani, A. I., dan Dwi, S. D. (2014). Hubungan Pola Asuh Ibu dengan Kejadian Stunting Anak Usia 24-59 Bulan di Posyandu Asoka II Wilayah Pesisir Kelurahan Barombong Kecamatan Talamate Kota Makasar Tahun 2014. Al-Sihah: Public Health Science Jurnal: 4 (2). ISSN $2086-2040$.

Ronyoet, B. S., Venie, H. dan Siti, N. R. (2013). Hubungan Pola Asuh dengan Kejadian Stunting pada Anak Usia 6-23 Bulan di Wilayah Pesisir Kecamatan Tallo Kota Makassar. Skripsi: Program Studi Ilmu Gizi Fakultas Ilmu Kesehatan Masyarakat Universitas Hasanuddin Makasar.

Rosha, B. C., Hardiansyah dan Baliwati, Y. F. (2012). Analisis Determinan Stunting pada Anak 0-23 Bulan pada Daerah Miskin di Jawa Tengah dan Jawa Timur. Panel Gizi Makanan, 35(1): 3441.

Santoso, S. dan Anne, L. R. (2009). Kesehatan dan Gizi. Jakarta: PT. Rineka Cipta.

Sekartini, R. dan Jeanne, R. T. (2013). Air Susu Ibu dan Tumbuh Kembang Anak: Buku Bedah ASI IDAI. Dilihat 30 November 2017 di http://www.idai.or.id/artikel/klinik/asi/air-susu-ibu-dantumbuh-kembang-anak.

Suhardjo. (2010). Pemberian Makanan Bayi dan Anak. Yogyakarta: Kanisius; 2010

Suhardjo \& Kusharto, C. M. (2010). Prinsip-prinsip Ilmu Gizi. Yogyakarta: KANISIUS

Sulistyoningsih, H. (2011). Gizi untuk Kesehatan Ibu dan Anak. Yogyakarta: Graha Ilmu

Supariasa, I. D. N., Bakri, B., dan Fajar, I. (2012). Penilaian Status Gizi. Jakarta: EGC

WHO. (2010). Nutrition Landscape Information System (NLIS) Country Profile Indicators: Interpretation Guide. Switzerland: WHO Press 